\title{
Aplikasi SMS-TI dengan VB.NET
}

\author{
Herpendi \\ Jurusan Teknik Informatika, Politeknik Negeri Tanah Laut \\ Jl. A. Yani Km. 6 Pelaihari Tanah Laut Kalimantan Selatan \\ Telp. (0512) 21357, Faks. (0512) 21537 \\ herpendi@politala.ac.id
}

\begin{abstract}
Abstrak - SMS merupakan sebuah layanan yang ada di setiap telepon genggam (handphone). 100\% mahasiswa Prodi Teknik Informatika Politeknik Negeri Tanah Laut memiliki handphone, bervariasi dari yang mendukung fasilitas sosial media di internet dan yang tidak seperti Nokia 110 salah satunya. Berkembang pesatnya aplikasi media sosial memberikan kemudahan dalam pertukaran informasi, salah satunya lewat fitur grup. Mahasiswa yang memiliki handphone dengan dukungan aplikasi sosial media tergabung minimal pada 1 grup sosial media, namun tidak seluruhnya mahasiswa tergabung dalam 1 grup yang sama dikarenakan banyaknya aplikasi sosial media dan minat mahasiswa yang berbeda terhadap sebuah aplikasi sosial media yang ada. Fitur SMS di setiap handphone mahasiswa bisa dijadikan media penyampaian informasi secara terpusat dari Prodi dengan bantuan aplikasi pengelolaan grup mahasiswa berdasarkan nomor telepon mahasiswa. Aplikasi dibangun menggunakan VB.NET. Dengan aplikasi ini informasi dapat terdistribusi dengan tepat ke setiap mahasiswa, baik ke mahasiswa yang menggunakan handphone dengan dukungan aplikasi sosial media maupun yang tidak.
\end{abstract}

Kata Kunci: Aplikasi, SMS, VB.NET

\section{PENDAHULUAN}

Handphone atau telepon seluler adalah perangkat telekomunikasi elektronik yang mempunyai kemampuan dasar yang sama dengan telepon konvensional saluran tetap, namun dapat dibawa ke mana-mana (portabel/mobile) dan tidak perlu disambungkan dengan jaringan telepon menggunakan kabel (nirkabel wireless). Saat ini, Indonesia mempunyai dua jaringan telepon nirkabel yaitu sistem GSM (Global System for Mobile Telecommunications) dan sistem CDMA (Code Division Multiple Access). Badan yang mengatur telekomunikasi seluler Indonesia adalah Asosiasi Telekomunikasi Seluler Indonesia (ATSI).

Hingga tahun 2014 data dari Menkominfo (Kementerian Komunikasi dan Informatika Republik Indonesia) pengguna handphone di Indonesia mencapai 270 juta dengan rasio kepemilikan ponsel paling banyak di DKI Jakarta yakni 1,8 ponsel per orang (Menkominfo, 2014). Angka tersebut melebihi jumlah penduduk Indonesia yang berkisar 255 juta jiwa.

Mahasiswa Prodi Teknik Informatika (TI) Politeknik Negeri Tanah Laut terhitung di Februari 2017 berjumlah 296 orang, terdiri dari 130 orang mahasiswa semester 2, 104 orang mahasiswa semester 4, dan 62 mahasiswa semester 6. Masing-masing mahasiswa tersebut memiliki handphone yang terdiri dari berbagai macam merek baik yang didukung dengan fasilitas sosial media (internet) maupun yang tidak. Produsen handphone merekapun beraneka ragam seperti Apple, Samsung, Xiaomi, Lenovo, Nokia, Asus, Acer, Evercross, Sony, Blackberry, Advance, dan Hi-tech.

Mahasiswa TI yang memiliki handphone dengan dukungan aplikasi sosial media telah memiliki akun di sosial media seperti Facebook, Twitter, Line, Whatsapp, Telegram, BBM, Path, Pinterest, atau Instagram. Disamping akun personal, mereka juga memiliki grup pertemanan minimal di satu di aplikasi sosial media yang sama.

Fitur grup yang ada di sosial media sangat memberikan manfaat sebagai media pertukaran informasi yang bersifat umum dan cepat, dimana setiap anggota yang mengirimkan pengumuman atau berita bisa langsung dilihat oleh semua anggota yang tergabung di dalamnya. Bagi mahasiswa TI grup biasanya dimanfaatkan sebagai media pengumuman dan pertukaran informasi yang berkaitan dengan kegiatan kampus, materi perkuliahan, tugas, diskusi dan sebagainya.

Prodi TI termasuk yang memanfaatkan fitur grup sosial media sebagai media pengumuman bagi mahasiswa yang berkaitan dengan kegiatan perkuliahan dan program Prodi, ini dilakukan karena salah satunya ialah rendahnya minat mahasiswa dalam memantau mading-mading yang ada. Salah satu grup yang ada ialah Facebook, namun tidak semua mahasiswa tergabung di grup dikarenakan tidak semuanya memiliki akun Facebook. Penyebab tidak adanya akun Facebook ini ialah karena handphone mahasiswa yang bersangkutan tidak didukung oleh fasilitas sosial media, seperti Nokia 110 dan Samsung E1272. Beberapa mahasiswa tersebut telah mencoba membuat akun Facebook lewat laptop dan sudah tergabung di grup, namun kembali terkendala informasi yang didapat tidak real time sebab tidak setiap saat laptop aktif dan dibawa kemanapun seperti halnya sebuah handphone.

SMS (Short Message Service) merupakan fasislitas mendasar yang ada di setiap handphone baik yang 
didukung aplikasi sosial media maupun tidak. SMS bisa dimanfaatkan untuk mengganti kelemahan yang ada di grup media sosial di Prodi TI. Dengan bantuan sebuah aplikasi khusus pengelola nomor kontak mahasiswa, pesan bisa dikirim secara real time dan diterima oleh semua mahasiswa. Lewat aplikasi ini juga bisa dibentuk grup-grup perkelas, per angkatan, dan juga untuk para alumni dan dosen, sehingga informasi bisa disampaikan sesuai target yang diinginkan secara tepat. Aplikasi dibangun dengan database system sehingga mampu menyimpan data nomor kontak dan pesan dalam kapasistas besar, tidak terbatas seperti penyimpanan telpon dan SIM Card. System database juga lebih menguntungkan karena data bisa diamankan (back-up) sewaktu-waktu.

\section{TINJAUAN PUSTAKA}

\subsection{Landasan Teori}

\subsubsection{Aplikasi}

Aplikasi berasal dari kata application yaitu bentuk benda dari kata kerja to apply yang dalam bahasa Indonesia berarti pengolah. Secara istilah, aplikasi komputer adalah suatu sub kelas perangkat lunak komputer yang menggunakan kemampuan komputer langsung untuk melakukan suatu tugas yang diinginkan pemakai.

Aplikasi bergerak (mobile application) adalah suatu aplikasi yang dibuat secara khusus untuk berjalan pada mobile device. Mobile device ini pada umumnya dikelompokkan berdasarkan platformnya (VanWellis, 2012).

\subsubsection{Modem}

Modem digunakan sebagai media SMS, dimana kartu SIM diletakkan di dalam modem ini. Modem yang digunakan dalam ini ialah modem GSM Huawei E153. Modem ini mendukung 3G dan memiliki slot Micro SD. Modem Huawei E153 tampak seperti gambar berikut:

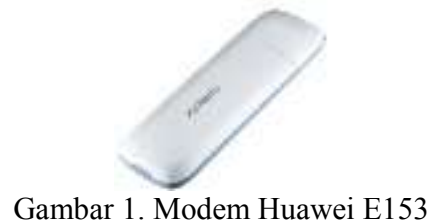

\subsubsection{SMS (Short Message Service)}

SMS merupakan salah satu fitur GSM yang dikembangkan dan distandarisasi oleh ETSI (European Telecomminucations Standards Institute) untuk mengirim atau menerima pesan singkat (Wahana Komputer, 2005). SMS terdiri dari 2 layanan dasar, yaitu:

1) Short Message Mobile Terminated (SM MT), yaitu kemampuan sistem GSM untuk menyampaikan pesan pendek yang dikirimkan dari Service Centre (SC) ke satu Mobile Station (MS), dan menghasilkan informasi tentang pengiriman itu baik delivery report atau status report dengan mekanisme tertentu. Seperti terlihat pada Gambar 1.

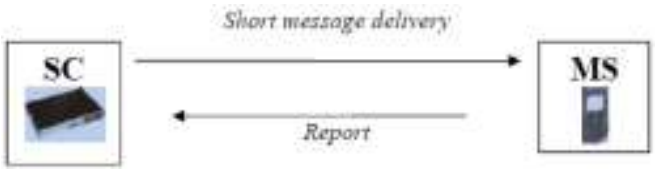

Gambar 2. Short Message Mobile Terminated SC MS

2) Short Message Mobile Oriented (SM MO), yaitu kemampuan dari sistem GSM untuk menyampaikan pesan pendek yang dikirimkan dari Mobile Station (MS) ke satu Short Message Entity (SME) melalui sebuah Service Centre (SC), dan menghasilkan informasi tentang pengiriman itu baik delivery report atau failure report. Perhatikan Gambar 2.

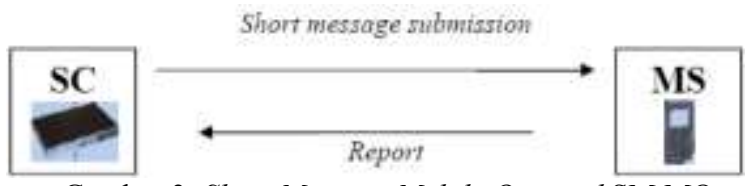

Gambar 3. Short Message Mobile Oriented SM MO

\subsubsection{Microsoft Visual Studio 2010 (VB.NET)}

Microsft Visual Studio merupakan sebuah perangkat lunak lengkap (suite) yang dapat digunakan untuk melakukan pengembangan aplikasi, baik itu aplikasi bisnis, aplikasi personal, ataupun komponen aplikasinya, dalam bentuk aplikasi console, aplikasi Windows, ataupun aplikasi Web (Yuswanto, 2010).

\subsubsection{MySQL}

Menurut (Sofwan, 2011), MySQL adalah sebuah implementasi dari sistem manajemen basisdata relasional (RDBMS) yang didistribusikan secara gratis dibawah lisensi GPL (General Public License). Setiap pengguna dapat secara bebas menggunakan MySQL, namun dengan batasan perangkat lunak tersebut tidak boleh dijadikan produk turunan yang bersifat komersial. MySQL sebenarnya merupakan turunan salah satu konsep utama dalam basisdata yang telah ada sebelumnya; SQL (Structured Query Language). SQL adalah sebuah konsep pengoperasian basisdata, terutama untuk pemilihan atau seleksi dan pemasukan data, yang memungkinkan pengoperasian data dikerjakan dengan mudah secara otomatis.

\subsection{Penelitian Terkait}

Penelitian yang dilakukan oleh Putri dkk di TK Xaverius 5 Palembang dengan judul "Pemanfaatan SMS Gateway dalam Pelayanan Informasi Aktifitas Siswa" menghasilkan kesimpulan bahwa sistem yang dikembangkan dapat mempermudah pihak sekolah dalam menyampaikan pengumuman penting melalui broadcast pesan (Ardy \& Atista, 2013).

Penelitian yang dilakukan oleh Hayati, et al. dengan judul "Sistem Informasi Pembayaran Berbasis Web dan SMS Broadcast (Studi Kasus: SMP Muhammadiyah 03 Semarang)" menghasilkan kesimpulan bahwa sistem informasi yang dibangun dapat menginformasikan tunggakan pembayaran 
kepada orang tua melalui SMS broadcast, sehingga orang tua dapat memantau pembayaran siswa (Hayati dkk, 2013).

Penelitian yang dilakukan oleh Novianti dan Fauzijah dengan judul "Sistem Informasi Sekolah Dasar Berbasis SMS" menghasilkan kesimpulan bahwa sistem yang dibangun mampu mengirimkan broadcast pesan ke semua orang tua siswa dan diharapkan mampu mempermudah, mempercepat sekaligus menghemat biaya dalam perolehan informasi yang dibutuhkan oleh orang tua siswa (Novianti \& Fauzijah, 2009).

Para peneliti di atas telah membuktikan bahwa dengan media SMS yang diintegrasikan dengan aplikasi komputer dapat membantu mempermudah dalam penyampaian informasi kepada orang tua siswa. Begitu pula dengan sistem yang dibangun pada penelitian ini ialah agar informasi mampu didapat secara tepat kepada sasaran (mahasiswa) tidak terbatas dengan spesifikasi dan kemampuan handphone yang dimiliki mahasiswa.

\section{METODE PENELITIAN}

\subsection{Pendekatan Penelitian}

Gambar 4 berikut menunjukkan proses kerja penelitian ini yang dimulai dengan pendeteksian Problem yang mana didapatkan masalah bahwa penyampaian informasi terhadap mahasiswa masih bersifat parsial sehingga diperlukan sebuah media atau aplikasi yang bisa mengakomodir penyampaian informasi terhadap seluruh mahasiswa secara menyeluruh. Dilanjutkan dengan Pendekatan yaitu dengan merancang menu dan form aplikasi yang sesuai dengan kebutuhan. Selanjutnya dilakukan Pengembangan dengan penulisan kode-kode program ke dalam VB.NET. Kemudian dilakukan Penerapan dengan pengujian form dan kode program sehingga memperoleh Hasil program yang bisa dijalankan.

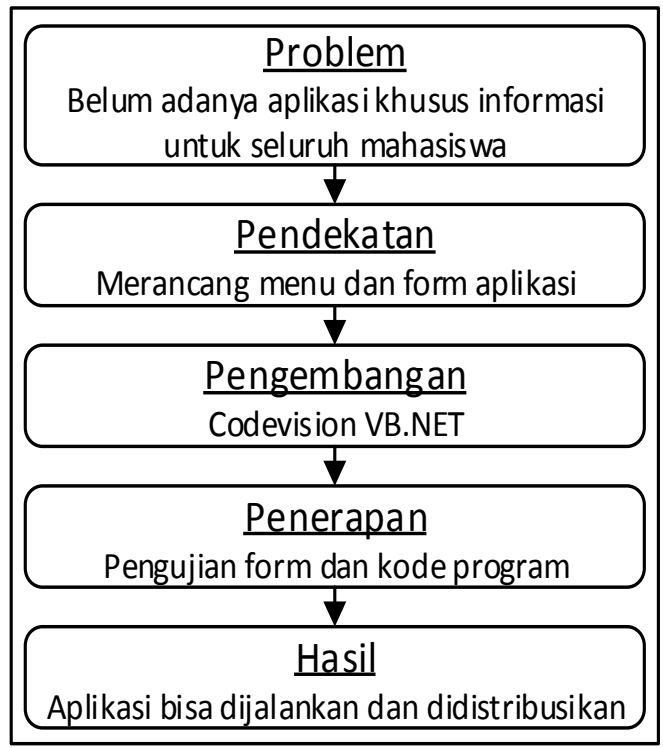

Gambar 4. Pendekatan Penelitian

\subsection{Metode Pengumpulan Data \\ 3.2.1 Studi Pustaka}

Studi pustaka dilakukan untuk memperoleh informasi serta data-data yang berkaitan dengan pembangunan sistem yang bersumber dari buku, modul, buku elektronik, dokumen elektronik, jurnal, hasil penelitian sejenis, dan website.

\subsubsection{Wawancara}

Pertama wawancara dilakukan dengan Ketua Prodi TI. Wawancara ini bertujuan untuk memperoleh informasi mengenai proses penyampaian informasi berupa pengumuman kepada mahasiswa. Selanjutnya dilakukan wawancara kepada staf Prodi berkenaan dengan teknis penyampain pengumuman. Disamping itu wawancara juga dilakukan terhadap beberapa orang mahasiswa dengan tujuan untuk mengetahui seberapa jauh informasi yang telah didapat lewat pengumuman di sosial media.

\subsubsection{Observasi}

Observasi dilakukan langsung kepada mahasiswa untuk mengetahui jumlah mahasiswa aktif, jumlah handphone yang dimiliki, jenis handpone yang dimiliki serta akun-akun personal dan grup yang dimiliki oleh mahasiswa.

\section{PEMBAHASAN}

\subsection{Perancangan Sistem}

Diagram Konteks pada Gambar 5 mendeskripsikan gambaran penggunaan sistem. Staf Prodi adalah orang yang berperan mengelola data nomor kontak dan pengiriman broadcast pesan pengumuman di dalam sistem / aplikasi. Sedangkan mahasiswa adalah objek yang akan menerima broadcast pesan pengumuman yang telah diolah dari sistem / aplikasi. Sistem yang digambarkan dengan Diagram Konteks bisa dilihat pada Gambar 5 berikut:

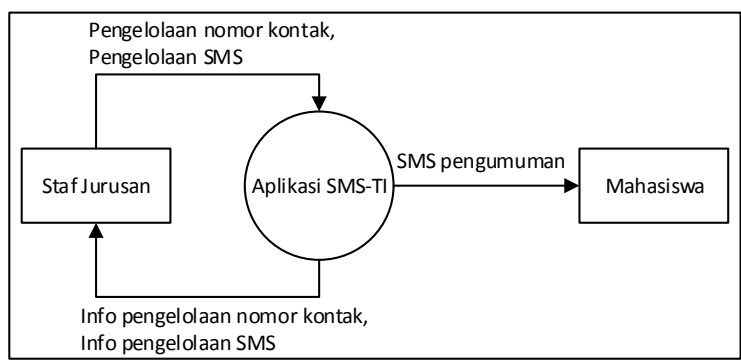

Gambar 5. Gambar Diagram Konteks

\subsection{Implementasi Perangkat Lunak \\ 4.2.1 Implementasi Antarmuka \\ 4.2.1.1 Halaman Login}

Halaman Login ialah halaman validasi untuk Staf Prodi untuk bisa masuk ke program aplikasi Terdapat 2 (dua) isian yang harus diisi sebelum masuk ke dalam aplikasi yaitu username dan password, tujuannya ialah untuk sistem keamanan agar tidak sembarang orang bisa mengkases aplikasi yang dibangun. Tampilan halaman Login tampak pada Gambar 6 berikut: 


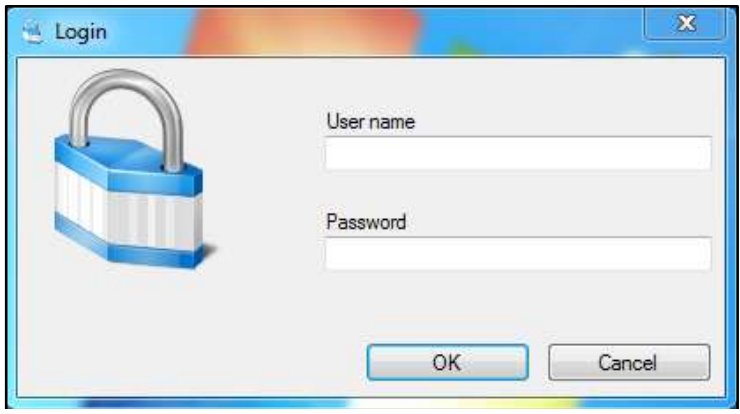

Gambar 6. Halaman Login

\subsubsection{Halaman Menu Utama}

Halaman menu utama atau lebih sering disebut beranda ini ialah tampilan awal saat aplikasi diakses. Di dalam beranda ini terdapat 6 (enam) button pilihan yaitu Buku Telepon, Tulis Pesan, Tulis Pesan Group, Pesan Masuk, Pesan Terkirim dan Ganti Password. Tampilan beranda tampak pada Gambar 7 berikut:

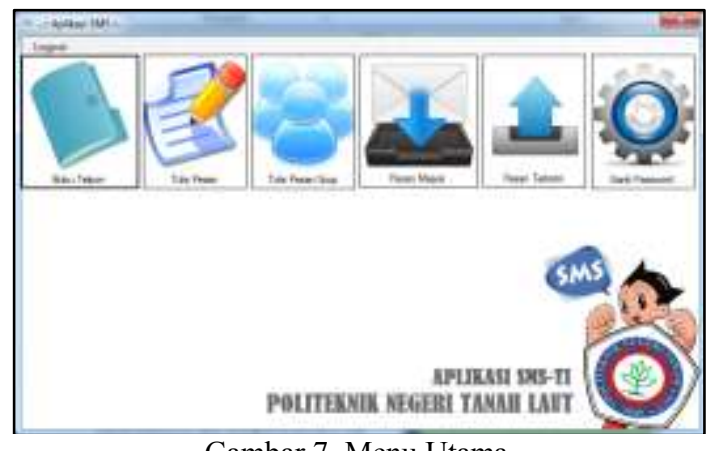

Gambar 7. Menu Utama

\subsubsection{Halaman Buku Telepon}

Ketika pada menu utama diklik button Buku Telepon, maka akan tampil form baru dan menyediakan 2 (dua) pilihan pengelolaan Buku Telepon yaitu Grup dan Member. Grup untuk menambah nama grup baru sedangkan Member untuk menambah per individu mahasiswa. Tampilan halaman Buku Telepon bisa dilihat pada Gambar 8 berikut:

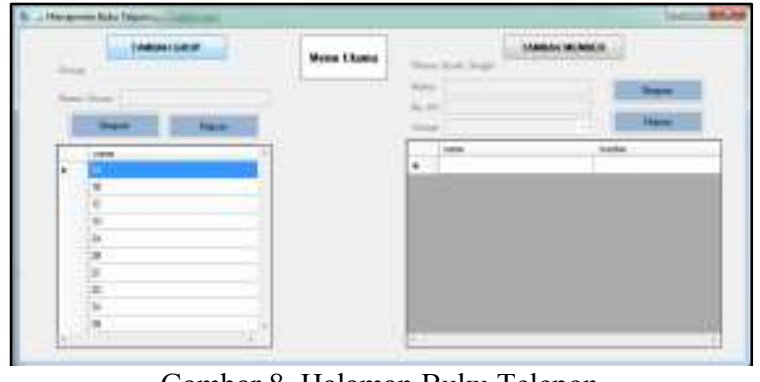

Gambar 8. Halaman Buku Telepon

\subsubsection{Halaman Tulis Pesan}

Ketika pada halaman menu utama diklik button Tulis Pesan, maka akan tampil form untuk menulis pesan yang bisa dikirmkan ke personal mahasiswa (bukan grup). Tampilan Halaman Tulis Pesan bisa dilihat pada Gambar 9 berikut:

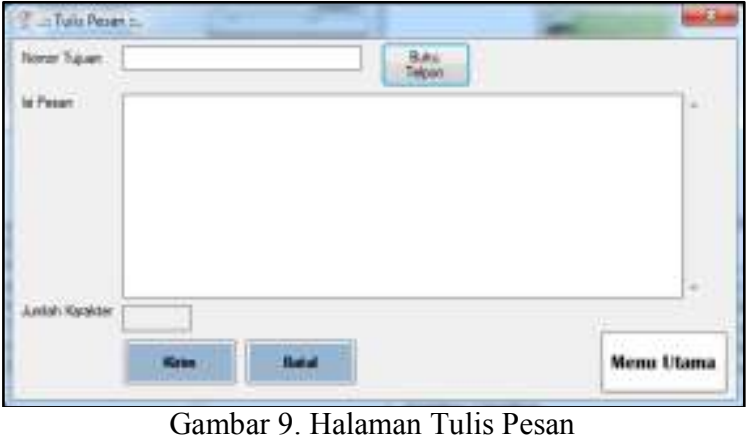

\subsubsection{Halaman Tulis Pesan Grup}

Ketika pada menu utama diklik button Tulis Pesan Grup, maka akan tampil form untuk menulis pesan grup atau broadcast. Tampilan Halaman Tulis Pesan Grup bisa dilihat pada Gambar 10 berikut:

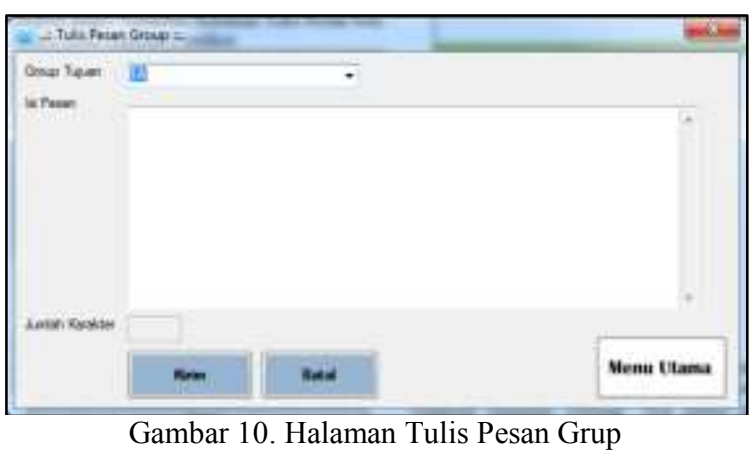

\subsubsection{Halaman Pesan Masuk}

Ketika pada menu utama diklik button Pesan Masuk, maka akan tampil SMS yang masuk ke aplikasi dan Staf Prodi bisa membalas pesan yang masuk dengan klik button Balas. Tampilan Halaman Pesan Masuk bisa dilihat pada Gambar 11 berikut:

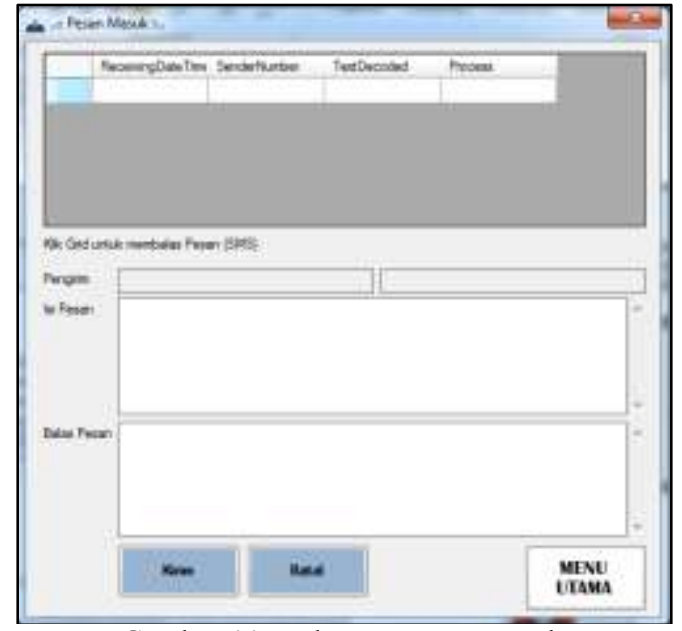

Gambar 11. Halaman Pesan Masuk

\subsubsection{Halaman Pesan Terkirim}

Ketika pada menu utama diklik button Tulis Pesan Terkirim, maka akan tampil daftar pesan / pengumuman yang telah dikirimkan ke mahasiswa. Tampilan Pesan Terkirim bisa dilihat pada Gambar 12 berikut: 


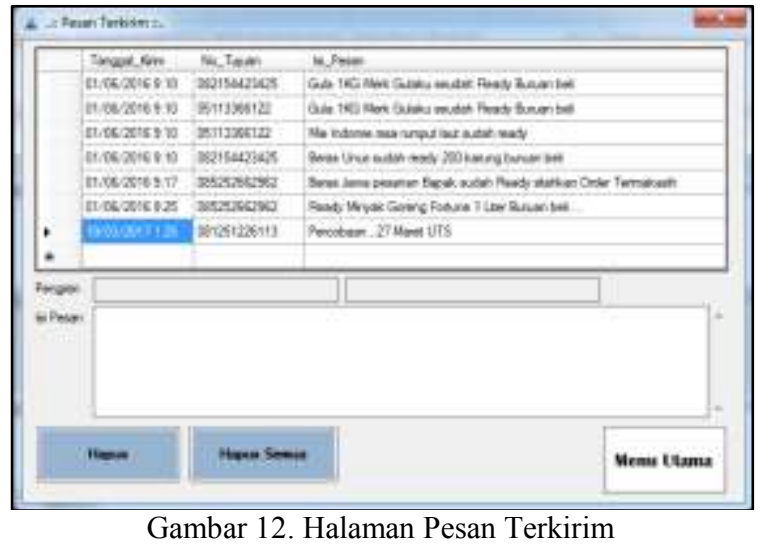

\subsubsection{Halaman Ganti Password}

Ketika pada menu utama diklik button Ganti Password, maka akan tampil form yang bisa digunakan Staf Prodi untuk mengupdate passwordnya untuk kepentingan keamanan. Tampilan Ganti Password bisa dilihat pada Gambar 13 berikut:

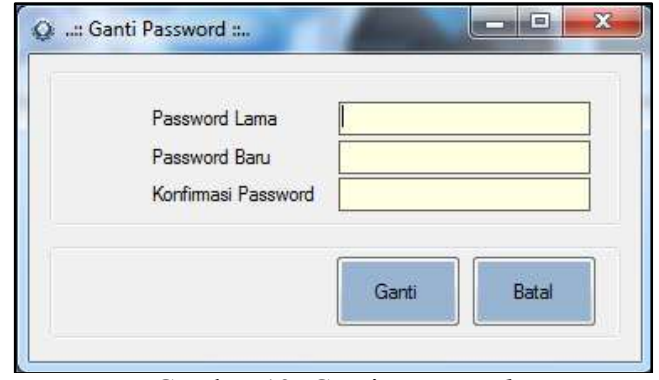

Gambar 13. Ganti Password

\subsubsection{SMS Broadcast Pesan}

Ketika Staf Prodi mengrimkan SMS ke mahasiswa maka SMS akan diterima oleh mahasiswa. Tampilan Ganti SMS Broadcast Pesan bisa dilihat pada Gambar 14 berikut:

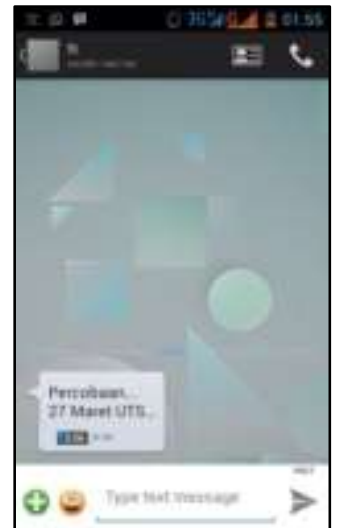

Gambar 14. SMS Broadcast Pesan

\subsubsection{Pengujian Blackbox}

Aplikasi SMS-TI sebelum dilakukan Setup and Deployment harus dilakukan pengujian untuk mengetahui apakah terdapat kegagalan dalam kode program dan sebagainya. Fungsi-fungsi menu yang telah diuji dan berhasil bisa dilihat pada Tabel 1 berikut.

Tabel 1. Pengujian Blackbox pada Aplikasi SMS-TI.

\begin{tabular}{|l|l|c|}
\hline No & \multicolumn{1}{|c|}{ Skenario Pengujian } & $\begin{array}{c}\text { Hasil } \\
\text { Pengujian }\end{array}$ \\
\hline 1 & Fungsi Halaman Login & Berhasil \\
\hline & Fungsi Halaman Menu Utama & Berhasil \\
\hline 2 & Fungsi Halaman Buku Telepon & Berhasil \\
\hline 3 & Fungsi Halaman Tulis Pesan & Berhasil \\
\hline 4 & $\begin{array}{l}\text { Fungsi Halaman Tulis Pesan } \\
\text { Group }\end{array}$ & Berhasil \\
\hline 5 & Fungsi Halaman Pesan Masuk & Berhasil \\
\hline 6 & Fungsi Halaman Pesan Terkirim & Berhasil \\
\hline 7 & Fungsi Halaman Ganti Password & Berhasil \\
\hline
\end{tabular}

\section{KESIMPULAN}

Aplikasi SMS-TI yang dibangun dapat menjadi solusi dalam penyampaian pengumuman secara tepat terhadap mahasiswa yang ada di Prodi TI. Segala fitur yang tersedia dalam aplikasi telah diuji fungsinya dan layak diterapkan di lapangan.

Karakteristik dari aplikasi ini adalah dapat mengirimkan broadcast pesan kepada seluruh mahasiswa (grup). Selain itu juga dapat mengirim pesan ke personal / individu mahasiswa (bukan grup). Aplikasi ini dapat digunakan oleh Prodi lain di lingkungan Politeknik Negeri Tanah Laut.

\section{DAFTAR PUSTAKA}

Ardy, R.P. \& Atista, R. 2013. Pemanfaatan SMS Gateway dalam Pelayanan Informasi Aktifitas Siswa pada TK Xaverius 5 Palembang. Skripsi. Palembang: STMIK MDP \& MDP Business School.

Hayati, M.R., Migunani \& Hakim, F.N. 2013. Sistem Informasi Pembayaran SPP Berbasis Web dan SMS Broadcast (Studi Kasus: SMP Muhammadiyah 03 Semarang). Jurnal Teknologi Informasi dan Komunikasi, Vol. 4 No. 2.

Menkominfo. 2014. Menkominfo: 270 Juta Pengguna Ponsel di Indonesia, (Online), (https://ugm.ac.id/id/berita/8776-menkominfo:

270.juta.pengguna.ponsel.di.indonesia, diakses 16 Maret 2017).

Novianti, A. \& Fauzijah, A. 2009. Sistem Infromasi Sekolah Dasar Berbasis SMS. SNATI 2009.

Sofwan, A. 2011. Belajar Mysql dengan Phpmyadmin, (Online),

(http://ilmukomputer .org/wpcontent/uploads/2011 /08/sofwanmysqldanphpmyadmin.pdf, diakses 10 November 2016).

VanWellis. 2012. VinnoMobile, (Online), (http://www.vanwellis.com/newvanwellis/mobileapplication-development.php, diakses 10 November 2016).

Wahana Komputer. 2005. Pengembangan Aplikasi Sistem Informasi Akademik Berbasis SMS dengan Java. Jakarta: Salemba Infromatika. 
Yuswanto. 2010. Boom..! VB.NET 2010 Meledak. Jakarta: Cerdas Pustaka Publisher.

\section{Biodata Penulis}

Herpendi, M.Kom, dilahirkan di Gunung Makmur, 20 November 1990. Tamat Sekolah Dasar (SD) Negeri Gunung Makmur 1, Takisung 2003. Sekolah Lanjutan Tingkat Pertama (SMP) diselesaikan tahun 2006 di SMPN 1 Takisung. Lulus Sekolah Menengah
Kejuruan (SMK) 1 Negeri Tanah Laut tahun 2009. Tahun 2009 mulai kuliah di Universitas Kalimantan Muhammad Arsyad Al-Banjary dan lulus sarjana pada tahun 2013 dengan gelar S.Kom. Pendidikan pascasarjana (S-2) ditempuh tahun 2013 dan lulus tahun 2015 dengan gelar Magister Komputer (M.Kom). Menjadi Dosen Tetap di lingkungan Politeknik Negeri Tanah Laut terhitung Januari 2016. 